\title{
Pola bakteri aerob yang berpotensi menyebabkan infeksi nosokomial di Instalasi Gawat Darurayt RSAD Robert Wolter Mongisidi Manado
}

\author{
${ }^{1}$ Sitti N. Gobel \\ ${ }^{2}$ Fredine E.S Rares \\ ${ }^{2}$ Heriyannis Homenta
}

\author{
${ }^{1}$ Kandidat Skripsi Fakultas Kedokteran Universitas Sam Ratulangi Manado \\ ${ }^{2}$ BagianMikrobiologi Fakultas Kedokteran Universitas Sam Ratulangi Manado \\ Email: novygobel13@gmail.com
}

\begin{abstract}
Nosocomial infection or Hospital Acquired infection (HAI) is caused by bacteria, parasites or viruses in hospitals and occurs after $\geq 48$ hours of hospital admission. Emergency room is te starting place procedures and or medical measures so that the room IGD became one of the places that produces a lot of waste of medical procedures performed and as one of the places most likely to transmit the infection. This study was aimed to determine the sources and patterns of aerobic bacteria that could potentially cause nosocomial infections: in the walls, floors, medical equipment, and ambient air of Emergency Room Robert Wolter Mongisidi Hospital, Manado. This was a descriptive prospective study with a cross sectional design. Samples were bacteria in the walls, floors, medical equipment, and the ambient air of the room IGD in the emergency room, Robert Wolter Mongisidi Hospital, Manado. The results showed that of the 29 samples taken, one sample did not contain any bacteria. There were eight types of bacteria found: Bacillus sp (33\%), Staphylococcus sp (27\%) Enterobacter agglomerans (13\%), Escherichia coli (10\%), Streptococcus sp (10\%), Serratia marcescens (3\%), Neisseria sp (2\%) and Klebsiella pneumoniae
\end{abstract} (2\%). Conclusion: The most common bacteria was Bacillus $s p$.

Keywords: IGD, nosocomial infections, patterns of aerobic bacteria

\begin{abstract}
Abstrak: Infeksi nosokomial atau Hospital Acquired infection (HAI) merupakan infeksi yang disebabkan oleh bakteri, parasit atau virus di rumah sakit, terjadi $\geq 48$ jam sejak masuk rumah sakit. Ruangan IGD merupakan tempat awal pasien mendapatkan prosedur dan atau tindakan medis sehingga ruangan IGD menjadi salah satu tempat yang banyak menghasilkan limbah hasil prosedur dan tindakan medis yang dilakukan serta salah satu tempat yang paling mungkin menularkan infeksi. Penelitian ini bertujuan untuk mengetahui sumber dan pola bakteri aerob yang berpotensi menyebabkan infeksi nosokomial: di dinding, lantai, peralatan medis, dan udara di ruang IGD pada ruang gawat darurat medik RSAD Robert Wolter Mongisidi Manado. Jenis penelitian ialah deskriptif prospektif dengan desain otong lintang. Sampel penelitian ialah bakteri pada dinding, lantai, peralatan medis, dan udara di ruang gawat darura tmedik RSAD Robert Wolter Mongisidi Manado. Hasil penelitian memperlihatkan dari 29 sampel yang diambil 1 sampel tidak terdapat bakteri. Terdapat 8 jenis bakteri yang ditemukan yaitu: Bacillus sp (33\%), Staphylococcus sp (27\%), Enterobacter agglomerans (13\%), Escherichia coli (10\%), Streptococcus sp (10\%), Serratia marcescens (3\%), Neisseria sp (2\%) dan Klebsiella Pneumoniae (2\%). Simpulan: Bakteri yang paling banyak ditemukan ialah Bacillus $s p$.
\end{abstract}

Kata kunci: IGD, infeksi nosokomial, pola bakteri aerob

Rumah Sakit adalah institusi pelayanan kesehatan yang menyelenggarakan pelayanan kesehatan perorangan secara paripurna yang menyediakan pelayanan rawat inap, rawat jalan, dan gawat darurat. ${ }^{1}$
Rumah sakit sebagai fasilitas pelayanan kesehatan memiliki indikator mutu (standar pelayanan minimal), salah satunya adalah presentasi angka kejadian infeksi nosokomial. Tingginya angka kejadian 
infeksi nosokomial mengindikasikan rendahnya kualitas mutu pelayanan kesehatan. Keputusan Menteri Kesehatan tentang Standar Pelayanan Minimal tahun 2008, bahwa standar tentang kejadian infeksi nosokomial yaitu $\leq 1,5 \%{ }^{2}$ Menurut WHO Health-care Associated Infection (HAIs) merupakan infeksi yang didapat selama menjalani prosedur perawatan dan tindakan medis dipelayanan kesehatan setelah $\geq 48$ jam dan setelah $\leq 30$ hari setelah keluar dari fasilitas pelayanan kesehatan. ${ }^{3}$ Infeksi nosokomial disebut juga sebagai infeksi yang berhubungan dengan pelayanan kesehatan atau Health-care Associated Infection (HAIs). ${ }^{4}$ Jenis infeksi yang paling sering terjadi adalah infeksi saluran kemih, infeksi saluran napas, infeksi luka, infeksi kulit dan jaringan lunak, dan septikemia. ${ }^{5}$ Ruangan IGD merupakan tempat awal pasien mendapatkan prosedur dan/atau tindakan medis sehingga ruangan IGD menjadi salah satu tempat yang banyak menghasilkan limbah hasil prosedur dan tindakan medis yang dilakukan serta salah satu tempat yang paling mungkin menularkan infeksi. ${ }^{6}$

Suatu penelitian yang dilakukan oleh WHO menunjukkan bahwa sekitar $8,7 \%$ dari 55 rumah sakit dari 14 negara yang berasal dari Eropa, Timur Tengah, Asia Tenggara dan Pasifik menunjukkan adanya infeksi nosokomial dan untuk Asia Tenggara sebanyak $10,0 \% .^{7} \mathrm{Di}$ Indonesia yaitu 10 RSU pendidikan, infeksi nosokomial cukup tinggi yaitu 6-16\% dengan rata-rata $9,8 \%$ pada tahun 2010 . Di Sulawesi utara angka kejadian infeksi nosokomial di BLU RSUP Prof. DR. R. D. Kandou Manado bulan Juli-Desember 2012, infeksi daerah luka operasi sebanyak $3,4 \%$, ISK sebanyak $2,7 \%$, infeksi aliran darah primer sebanyak $6,4 \%$, infeksi dekubitus sebanyak $0,7 \%{ }^{8}$

Berdasarkan temuan di atas dan sampai saat ini belum ada yang melakukan penelitian tentang pola bakteri aerob yang berpotensi menyebabkan infeksi nosokomial pada ruangan IGD RSAD Robert Wolter Mongisidi Manado, maka peneliti tertarik melakukan penelitian ini.

\section{METODE PENELITIAN}

Penelitian ini menggunakan metode penelitian deskriptif cross sectional dengan menggunakan pendekatan prospektif. Penelitian ini dilaksanakan pada Agustus sampai November 2016. Terdapat 29 sampel dalam penelitian ini yang berasal dari dinding, lantai, peralatan medis dan udara di ruang IGD pada ruang gawat darurat medik RSAD Robert Wolter Mongisidi Manado. Pengelolaan sampel dilakukan di Laboratorium Mikrobiologi Fakultas Kedokteran Universitas Sam Ratulangi Manado dengan pewarnaan Gram dan dilanjutkan dengan uji biokimia.

\section{HASIL PENELITIAN}

Berdasarkan penelitian yang dilakukan selama bulan Agustus-November 2016 telah dilakukan pengambilan sampel di ruang IGD pada ruangan gawat darurat medik RSAD Robert Wolter Mongisidi Manado.

Tabel 1. Distribusi Pengambilan Sampel

\begin{tabular}{ccc}
\hline Kategori & Sampel & $\begin{array}{c}\text { Jumlah } \\
\text { Sampel }\end{array}$ \\
\hline Ruang Gawat & Lantai & 5 \\
Darurat Medik & Dinding & 4 \\
Perabotan & Tempat & 1 \\
Ruangan & tidur & \\
Peralatan & Selang O & 1 \\
Medis & Kanul & 1 \\
& Oksigen & \\
& Alat & 1 \\
& Nebulizer & 1 \\
& Alat EKG & 5 \\
Udara & Pagi & 5 \\
& Siang & 5 \\
& Sore & $\mathbf{2 9}$ \\
\hline
\end{tabular}

Pada tabel 1 pengambilan sampel dilakukan di ruangan gawat darurat medik terdiri dari 29 sampel yaitu 5 sampel dari lantai 4 sampel dari dinding, 1 sampel dari tempat tidur, 4 sampel peralatan medis yaitu: 1 sampel selang oksigen, 1 sampel kanul oksigen, 1 sampel nebulizer, 1 
sampel alat EKG, dan 15 udara yaitu: 5 udara pagi, 5 udara siang dan 5 udara sore.

Pada tabel 2 dapat dilihat pertumbuhan bakteri pada Nutrien Agar sebanyak 29 sampel, Mac Conkey Agar sebanyak 21 sampel, dan Agar darah sebanyak 29 sampel, sedangkan yang tidak ada pertumbuhan bakteri hanya pada Mac Conkey Agar sebanyak 8 sampel.

Tabel 2. Distribusi Pertumbuhan Bakteri

\begin{tabular}{ccccc}
\hline $\begin{array}{c}\text { Media } \\
\text { Isolasi }\end{array}$ & \multicolumn{2}{c}{$\begin{array}{c}\text { Hasil } \\
\text { Pertumbuhan }\end{array}$} & \multicolumn{2}{c}{$\begin{array}{c}\text { Presentase } \\
\text { (\%) }\end{array}$} \\
& AP & TAP & AP & TAP \\
\hline $\begin{array}{c}\text { Nutrient } \\
\text { Agar }\end{array}$ & 29 & - & 37 & - \\
Mac & & & & \\
Conkey & 21 & 8 & 26 & 8 \\
Agar & & & & \\
Agar & 29 & - & 37 & - \\
Darah & & & & $\mathbf{1 0 0}$ \\
Total & $\mathbf{7 9}$ & $\mathbf{8}$ & $\mathbf{1 0 0}$ & $\mathbf{1 0 0}$ \\
\hline
\end{tabular}

Pada tabel 3 dapat dilihat Hasil pewarnaan Gram ditemukan 28 sampel terdapat bakteri dan 1 sampel tidak ditemukan adanya bakteri. Bakteri yang terbanyak pada pewarnaan Gram yaitu bakteri Gram positif.

Pada tabel 4 menunjukkan bakteri yang didapat berjumlah 60 bakteri yang di temukan pada 28 sampel, dan pada hasil identifikasi bakteri ditemukan 8 jenis bakteri yang banyak ditemukan yaitu Bacillus sp $(33 \%)$ pada sampel lantai, dinding, udara pagi, udara siang, udara sore, selang $\mathrm{O}_{2}$, kanul $\mathrm{O}_{2}$, nebulizer, EKG. Staphylococcus sp (27\%) pada sampel lantai, udara pagi, udara siang, udara sore, selang $\mathrm{O}_{2}$, kanul $\mathrm{O}_{2}$. Enterobacter agglomerans (13\%) pada sampel lantai, udara pagi, udara siang, EKG. Escherichia coli $(10 \%)$ pada sampel udara sore. Streptococcus sp (10\%) pada sampel lantai, dinding, udara pagi, udara siang, udara sore. Serratia marcescens (3\%) pada saampel tempat tidur. Neisseria sp (2\%) pada sampel udara sore dan Klebsiella Pneumoniae (2\%) pada sampel udara pagi.

Tabel 3. Hasil Pewarnaan Gram

\begin{tabular}{cccc}
\hline Pewarnaan Gram & Nutrien Agar & $\begin{array}{c}\text { Mac Conkey } \\
\text { Agar }\end{array}$ & Agar Darah \\
\hline Gram Positif & 17 & - & 25 \\
Gram Negatif & 9 & 9 & - \\
Total & $\mathbf{2 6}$ & $\mathbf{9}$ & $\mathbf{2 5}$ \\
\hline
\end{tabular}

Tabel 4. Hasil Identifikasi Bakteri Secara Keseluruhan

\begin{tabular}{|c|c|c|c|}
\hline Bakteri & Jumlah & $(\%)$ & Sampel \\
\hline Bacillus sp & 20 & 33 & $\begin{array}{l}\text { Lantai, dinding, udara pagi, udara siang, udara } \\
\text { sore, selang } \mathrm{O}_{2} \text {, kanul } \mathrm{O}_{2} \text {, nebulizer, EKG. }\end{array}$ \\
\hline Staphylococcus sp & 16 & 27 & $\begin{array}{l}\text { Lantai, udara pagi, udara siang, udara sore, } \\
\text { selang } \mathrm{O}_{2} \text {, kanul } \mathrm{O}_{2}\end{array}$ \\
\hline Enterobacter agglomerans & 8 & 13 & Lantai, udara pagi, udara siang, EKG \\
\hline Escerichia coli & 6 & 10 & Udara sore \\
\hline Streptococcus sp & 6 & 10 & $\begin{array}{l}\text { Lantai, dinding, udara pagi, udara siang, udara } \\
\text { sore }\end{array}$ \\
\hline Serratia marcescens & 2 & 3 & Tempat tidur \\
\hline Neisseria $\mathrm{Sp}$ & 1 & 2 & Udara sore \\
\hline Klebsiella Pneumoniae & 1 & 2 & Udara pagi \\
\hline Total & 60 & 100 & \\
\hline
\end{tabular}


Tabel 5 menunjukkan pertumbuhan 2 jenis bakteri pada dinding yaitu Bacillus sp (80\%) dan Streptococcus sp (20\%). Tabel 6 menunjukkan pertumbuhan 4 jenis bakteri yaitu Bacillus sp (55\%), Enterobacter agglomerans (27\%), Staphylococcus sp (9\%), Streptococcus Sp (9\%). Tabel 7 menunjukkan bakteri yang terdapat pada tempat tidur yaitu Serratia marcescens (100\%). Tabel 8 menunjukkan bakteri yang terdapat di peralatan medis ada 3 jenis bakteri yaitu: Bacillus sp (57\%), Staphylococcus sp (29\%) dan Enterobacter agglomerans (14\%).

Tabel 5. Bakteri pada Sampel Dinding

\begin{tabular}{ccc}
\hline Bakteri & Jumlah & $(\boldsymbol{\%})$ \\
\hline Bacillus $s p$ & 4 & 80 \\
Streptococcus $s p$ & 1 & 20 \\
Total & $\mathbf{5}$ & $\mathbf{1 0 0}$ \\
\hline
\end{tabular}

Tabel 6. Bakteri pada Sampel Lantai

\begin{tabular}{ccc}
\hline Bakteri & Jumlah & $\mathbf{( \% )}$ \\
\hline Bacillus $s p$ & 6 & 55 \\
Enterobacter & 3 & 27 \\
agglomerans & & 9 \\
Staphylococcus $s p$ & 1 & 9 \\
Streptococcus $s p$ & 1 & $\mathbf{1 0 0}$ \\
Total & $\mathbf{1 1}$ &
\end{tabular}

Tabel 7. Bakteri Pada Sampel Tempat tidur

\begin{tabular}{ccc}
\hline Bakteri & Jumlah & $\mathbf{( \% )}$ \\
\hline Serratia marcescens & 2 & 100 \\
Total & $\mathbf{2}$ & $\mathbf{1 0 0}$ \\
\hline
\end{tabular}

Tabel 8. Bakteri Pada Sampel Peralatan Medis

\begin{tabular}{|c|c|c|}
\hline Bakteri & Jumlah & Sampel \\
\hline Bacillus sp & $4(57 \%)$ & $\begin{array}{c}\text { Selang } \mathrm{O}_{2} \text {, kanul } \\
\mathrm{O}_{2} \text {, EKG, } \\
\text { Nebulizer }\end{array}$ \\
\hline $\begin{array}{c}\text { Staphylococcus } \\
s p\end{array}$ & $2(29 \%)$ & $\begin{array}{c}\text { Selang } \mathrm{O}_{2} \text {, kanul } \\
\mathrm{O}_{2}\end{array}$ \\
\hline $\begin{array}{l}\text { Enterobacter } \\
\text { agglomerans }\end{array}$ & $1(14 \%)$ & EKG \\
\hline Total & 7 (100) & \\
\hline
\end{tabular}

Tabel 9 menunjukkan bakteri yang tumbuh diudara pagi sebanyak 5 jenis bakteri yaitu Staphylococcus sp (50\%), Enterobacter agglomerans (20\%), Klebsiella pnemoniae (10\%), Streptococcus sp (10\%), dan Bacillus sp (10\%).

Tabel 9. Bakteri pada sampel Udara Pagi

\begin{tabular}{ccc}
\hline Bakteri & Jumlah & $(\boldsymbol{\%})$ \\
\hline Staphylococcus $s p$ & 5 & 50 \\
Enterobacter & 2 & 20 \\
agglomerans & & \\
Klebsiella & 1 & 10 \\
pneumoniae & & 10 \\
Streptococcus sp & 1 & 10 \\
Bacillus $s p$ & 1 & $\mathbf{1 0 0}$ \\
Total & $\mathbf{1 0}$ & \\
\hline
\end{tabular}

Tabel 10 menunjukkan bakteri yang ditemukan di udara siang terdapat 4 jenis bakteri yaitu Staphylococcus sp (50\%), Streptococcus sp (20\%), Enterobacter agglomerans (20\%) dan Bacillus sp (10\%).

Tabel 10. Bakteri Pada Sampel Udara Siang

\begin{tabular}{ccc}
\hline Bakteri & Jumlah & $(\boldsymbol{\%})$ \\
\hline Staphylococcus $s p$ & 5 & 50 \\
Streptococcus $s p$ & 2 & 20 \\
Enterobacter & 2 & 20 \\
agglomerans & & \\
Bacillus $s p$ & 1 & 10 \\
Total & $\mathbf{1 0}$ & $\mathbf{1 0 0}$ \\
\hline
\end{tabular}

Tabel 11 menunjukkan bakteri yang ditemukan pada sampel udara sore terdapat 5 jenis bakteri yaitu Eschericia coli (40\%), Bacillus sp (26\%) Staphylococcus sp (20\%), Neisseria sp (7\%) dan Streptococcus sp (7\%).

Tabel 11. Bakteri Pada Sampel Udara Sore

\begin{tabular}{ccc}
\hline Bakteri & Jumlah & $(\boldsymbol{\%})$ \\
\hline Escherichia coli & 6 & 40 \\
Bacillus $s p$ & 4 & 26 \\
Staphylococcus $s p$ & 3 & 20 \\
Neisseria $s p$ & 1 & 7 \\
Streptococcus $s p$ & 1 & 7 \\
Total & $\mathbf{1 5}$ & $\mathbf{1 0 0}$ \\
\hline
\end{tabular}




\section{BAHASAN}

Penelitian dilakukan di IGD RSAD Robert Wolter Mongisidi Manado pada periode Agustus-November 2016. Ruang IGD RSAD Robert Wolter Mongisidi terdiri dari ruang gawat darurat medik, ruang tindakan bedah dan ruang administrasi, tetapi penelitian ini hanya dilakukan di ruang gawat darurat medik.

Pengambilan sampel berupa usapan di ruang gawat darurat medik, perabotan ruangan, peralatan medis, dan udara di Instalasi Gawat Darurat RSAD Robert Wolter Mongisidi Manado sebanyak 29 sampel dan dilakukan pemeriksaan di Laboratorium Mikrobiologi Fakultas Kedokteran Universitas Sam Ratulangi Manado. Berdasarkan hasil yang didapatkan, pada penelitian sebanyak 29 sampel, bakteri yang tumbuh pada Nutrien Agar sebanyak 29 sampel (100\%), bakteri yang tumbuh pada Mac Conkey Agar sebanyak 21 sampel (72\%), dan bakteri yang tumbuh pada Agar Darah sebanyak 29 sampel (100\%). Setelah itu pewarnaan Gram dilakukan di Laboratorium Mikrobiologi Fakultas Kedokteran Universitas Sam Ratulangi Manado sebanyak 29 sampel. Hasil pewarnaan Gram ditemukan 28 sampel terdapat bakteri dan 1 sampel tidak ditemukan adanya bakteri.

Bacillus $s p$ merupakan flora normal di tanah, udara, air dan kompos tanah. Dalam penelitian ini ditemukan kuman yang terbanyak yaitu Bacillus sp pada sampel lantai, dinding, udara pagi, udara siang, udara sore, dan selang $\mathrm{O}_{2}$, kanul $\mathrm{O}_{2}$, alat nebulizer dan alat EKG. Dibandingkan dengan penelitian tentang Angka Kuman dan Pola Kuman pada dinding, lantai dan udara diruang ICU RSUD Dr. Moewardi Surakarta ditemukan kuman Bacillus sp terdapat pada sampel dinding, lantai, dan udara. ${ }^{9}$ Jadi sama-sama ditemukan kuman Bacillus sp pada sampel yang sama. Hal ini menunjukkan tingginya angka kuman lantai mungkin disebabkan oleh berbagai faktor misalnya penggunaan dosis desinfektan yang tidak sesuai, cara pemakaian desinfektan yang tidak baik dan pengepelan lantai yang seharusnya setiap saat belum dilaksanakan secara maksimal oleh petugas. Selain itu terdapatnya kuman dibeberapa sampel lainnya kemungkinan disebabkan karena kontaminasi.

Staphylococcus sp. merupakan flora normal pada kulit dan selaput lendir manusia. Pada penelitian ini bakteri yang ditemukan adalah Staphylococcus sp. yaitu pada sampel lantai, udara pagi, udara siang, udara sore, selang $\mathrm{O}_{2}$, kanul $\mathrm{O}_{2}$. Sedangkan di RPI anak yang diteliti, ditemukan Staphylococcus sp. sebanyak $16,67 \%$ pada sampel udara. Hal ini mungkin disebabkan karena bakteri ini bisa berasal dari selaput lendir pasien yang menempel diselang infus dan bisa juga bakteri ini tersebar di udara melalui batuk, bersin, berbicara, dan tertawa. Pada proses tersebut ikut keluar cairan saliva dan mukus yang mengandung mikroba. Bakteri ini bisa menyebabkan keracunan makanan dan toxic shock syndrome. ${ }^{10,11}$

Enterobacter agglomerans disebut juga Pantoea agglomerans adalah bakteri gram negatif yang tergabung dalam family Enterobacteriaceae, bakteri ini dikenal sebagai bakteri pathogen yang biasanya diisolasi dari permukaan tumbuhan, buah, dan feses hewan atau manusia. ${ }^{12}$ Pada penelitian ini bakteri Enterobacter agglomerans terdapat sekitar $13 \%$ yang di temukan pada sampel lantai, alat EKG, udara pagi dan udara siang. Pada penelitian tentang Pola Bakteri Aerob yang berpotensi menyebabkan infeksi noso-komial pada Kamar Bersalin RSAD Robert Wolter Mongisidi Manado pada alat USG ditemukan bakteri Gram negatif yaitu Enterobacter agglomerans. ${ }^{13}$ Jadi penelitian yang saya lakukan dibandingkan dengan penelitian sebelumnya sama-sama ditemukan bakteri Enterobacter agglomerans pada alat medis. Hal ini kemungkinan disebabkan karena kontaminasi dari luar.

Escherichia coli dalam penelitian ini ditemukan sebanyak $10 \%$ pada sampel udara sore hal ini dikarenakan penyebaran kuman melibatkan media lingkungan seperti udara dan vektor sebagai perantara 
atau kendaraan. Mikroorganisme patogen di udara termasuk bakteri, virus, jamur dan parasit dapat menyebabkan infeksi nosokomial. Di rumah sakit, infeksi ini dapat terjadi pada seseorang karena tertular oleh mikroorganisme dari orang lain atau oleh flora normal dari dirinya sendiri melalui persinggungan dengan makanan, udara, atau benda-benda yang tidak steril. ${ }^{14}$

Streptococcus sp ditemukan pada permukaan lantai, dinding, udara pagi, udara siang dan udara sore sebanyak (10\%). Dibandingkan dengan penelitian sebelumnya tentang infeksi nosokomial di Ruang Perawatan Intensif Anak Di BLU RSUP Prof. Dr. R. D. Kandou Manado bakteri ini ditemukan pada permukaan dinding yang diteliti. Peneliti menemukan bakteri ini sebanyak 3,33\% di RPI anak. ${ }^{10}$ Jadi, terdapat perbedaan antara ruangan IGD dengan RPI anak, hal ini dikarenakan ruang intensif memiliki keterbatasan pengunjung, sementara di ruang IGD pengunjung bisa lebih dari 3 , hal inilah yang menyebabkan bakteri dari luar bisa lebih mudah masuk ke dalam ruangan IGD dan berpotensi menyebabkan infeksi juga lebih tinggi.

Pada penelitian yang dilakukan di ruang UGD RSUP Abepura, Kota Jayapura di dapatkan sebanyak 12\% bakteri Serratia marcescens disampel udara. Dalam penelitian ini ditemukan pada sampel tempat tidur, hal ini mungkin disebabkan penyebaran mikroorganisme di udara bisa berasal dari partikel debu yang kebanyakan masuk ke dalam ruangan melalui sepatu, pakaian, dan karena sering terbukanya pintu serta tidak menutup kemungkinan juga bakteri ini bisa menempel di tempat tidur melalui pakaian pasien yang terkontaminasi. Droplet di udara yang terbentuk selama aktivitas manusia akan masuk dan berdistribusi melalui aliran udara, yang menyebabkan terjadinya risiko penularan infeksi yang berbahaya. ${ }^{15}$

Neisseria $s p$. merupakan bakteri udara paling banyak (55\%) yang ditemukan di inkubator bayi unit perinatologi Rumah Sakit Umum Daerah Dr. Abdul Moeloek. ${ }^{16}$ Dalam penelitian ini ditemukan bakteri
Neisseria Sp sebanyak 3\% di sampel udara sore. Jadi penelitian yang saya lakukan dibandingkan dengan penelitian sebelumnya sama. Hal ini mungkin disebabkan karena bakteri ini terpapar di udara melalui udara pernafasan, batuk, bersin, atau lewat percikan ludah. Bila daya tahan tubuh pejamu abnormal, bakteri tersebut dapat menimbulkan infeksi saluran nafas bagian atas yang kemudian masuk kedalam peredaran darah sehingga menyebabkan meningitis. ${ }^{17}$

Hasil penelitian yang dilakukan di ruang UGD RSUP Abepura, Kota Jayapura di dapatkan sebanyak $12 \%$ bakteri Klebsiella $S p$ di sampel udara. ${ }^{15}$ Dalam penelitian ini bakteri Klebsiella pneumoniae ditemukan sebanyak $2 \%$ pada sampel udara pagi. Jadi sama-sama di temukan adanya bakteri Klebsiella di sampel udara. Pada penelitian ini, peneliti menemukan bahwa pada ruang IGD, pengunjung yang datang bebas keluar masuk ke dalam ruangan. Hal ini bisa menyebabkan risiko infeksi nosokomial dari luar ke dalam ruangan semakin tinggi.

Lingkungan rumah sakit yang kurang baik akan memungkinkan terjadinya penularan penyakit yang dapat berpengaruh terhadap kesehatan masyarakat di lingkungan rumah sakit tersebut. Oleh karena itu pelayanan sanitasi rumah sakit perlu diselenggarakan dalam rangka menciptakan lingkungan yang bersih sehingga dapat mendukung usaha penyembuhan penderita dan dapat mencegah terjadinya penularan infeksi nosokomial di lingkungan rumah sakit. ${ }^{9}$

\section{SIMPULAN}

Berdasarkan hasil penelitian potensi sumber penularan infeksi nosokomial di IGD pada ruangan gawat darurat medik RASD Robert Wolter Mongisidi Manado periode Agustus-November 2016 di temukan sebanyak 8 jenis bakteri yaitu Bacillus Sp, Staphylococcus sp, Enterobacter Agglomerans, Escerichia Coli, Streptococcus Sp, Serratia Marcescens, Neisseria Sp dan Klebsiella Pneumoniae. Bakteri yang terbanyak ialah Bacillus Sp. 


\section{SARAN}

1. Penelitian ini dapat dilanjutkan dengan penelitian tentang uji kepekaan antibiotika pada bakteri penyebab infeksi nosokomial pada ruangan Instalasi Gawat Darurat RSAD Robert Wolter Mongisidi Manado.

2. Pihak rumah sakit agar lebih meningkatkan lagi sterilisasi dan sanitasi lingkungan rumah sakit, khususnya pada ruang IGD terutama dilakukan pembersihan secara rutin pada lantai dan tempat tidur pasien, karena pada saat saya melakukan penelitian petugas kebersihan tidak melakukan pembersihan, karena pada standarnya harus dibersihkan setelah ada pergantian pasien apalagi ini adalah ruangan darurat.

3. Pihak rumah sakit dianjurkan untuk dapat melakukan swab lingkungan secara berkala agar dapat mengetahui tingkat pencapaian kebersihan dan sterilisasi rumah sakit

\section{DAFTAR PUSTAKA}

1. Undang-Undang RI No. 44 Tahun 2009 Rumah Sakit.28 Oktober 2009. Lembaran Negara Republik Indonesia Tahun 2009 Nomor 153. Jakarta.

2. Kepmenkes No 129 Tahun 2008. Standar Pelayanan Mininal Rumah Sakit. Jakarta: Kementrian Kesehatan.

3. WHO. 2011. HAIs Surveilance. http://www.who.int/bulletin/volumes/8 9/10/11-088179/en/. (Cited 2016 Nov 14).

4. Kementerian Kesehatan Republik Indonesia. Surveilans infeksi di rumah sakit. [diunduh 2 September 2016]. Tersedia dari:

http://buk.depkes.go.id/index.php?optio $\mathrm{n}=\mathrm{com} \_$content $\&$ view $=$ article $\& \mathrm{id}=123$ : surveilans-infeksi-di-rumah sakit.

5. Bamford K, Gillespie S. At a Glance Mikrobiologi medis dan infeksi. Edisi ke-3. Jakarta: Erlangga; 2009. h. 245.6 .

6. Darmadi. Infeksi Nosokomial: Problematika Dan Pengendaliannya. Jakarta.: Penerbit Salemba Medika. 2008

7. Belaguris. Infeksi Nosokomial. http://infeksi-nosokomial.html. Diakses pada tanggal 2 september 2016.

8. Sofyan A, Homenta H, Rares FES. Pola bakteri aerob yang berpotensi menyebabkan infeksi nosokomial di kamar operasi cito BLU RSUP Prof. Dr. R. D. Kandou Manado. Jurnal eBiomedik. 2015;6.

9. Oktarini M. Angka dan Pola Kuman Pada Dinding, Lantai dan Udara di Ruang ICU RSUD Dr. Moewardi Surakarta. Universitas Muhammadiyah Surakarta. 2013

10. Baharutan A, Rares FES, Soelingan S. Pola bakteri penyebab infeksi nosokomial pada ruang perawatan intensif anak di BLU RSUP Prof. Dr. R. D. Kandou Manado. Jurnal eBiomedik. 2015; 3:1.

11. Medicinenet. Definition of Staphylococcus. 2012 [citied 2016 Nov 20]. Available from

http://www.medicinenet.com/script/mai n/art.asp?articlekey=5549

12. Rahmaningsih $\mathrm{S}$, Wlis $\mathrm{S}$, Mulyana $\mathrm{A}$. Ekologia, Vol.12 No. 1, April 2012: 15.

13. Ritto L, Soelingan S, Rares FES. Pola bakteri aerob yang berpotensi menyebabkan infeksi nosokomial pada Kamar Bersalin RSAD Robert Wolter Mongisidi Manado. Jurnal e-Biomedik. 2016; 4:1.

14. Adysaputra A, Rauf MA, Bahar B. Patterns and prevalence of nosocomial microbial infection from intensive care unit patients, Wahidin Sudirohusodo Hospital, Makassar. The Indonesian Journal of Medical Science. 2009; 2 (2): p. 67-70.

15. Sinaga H, Runtuboi D, Zebua L. Bakteri penyebab infeksi nosokomial pada alat kesehatan dan udara di ruang Unit Gawat Darurat RSUD Abepura, Kota Jayapura. Jurnal Biologi Papua. 2014; 6:75-79.

16. Imaniar E, Apriliana E, Rukmono $P$. Kualitas mikrobiologi udara di inkubator unit perinatalogi RSUD Dr. Abdul Moelek Bandar Lampung. Medical Journal of Lampung University. 2013;2.

17. Jawetz, Melnick, Adelberg. Mikrobiologi Kedokteran. Edisi ke-23. Jakarta: EGC; 2007. h.270. 